\title{
Species of fungi colonizing dying plants of Alpine lady-fern (Athyrium distentifolium Tausch ex Opiz) in the Karkonosze Mountains
}

\section{Grzyby zasiedlające zamierające rośliny wietlicy alpejskiej (Athyrium distentifolium Tausch ex Opiz) w Karkonoszach}

\author{
Wojciech Pusz ${ }^{1 *}$, Jacek Urbaniak², Andrzej Dunajski ${ }^{3}$
}

\section{Summary}

Phytopathological research was conducted in Karkonosze National Park in 2016-2017. The total of 17 isolates belonging to 13 fungal species and one taxa of fungi were isolated during the mycological analysis of infected tissue. Botrytis cinerea was identified in the samples representing each type of symptoms such as tissue discolorations, narrowing and nerve fractures. $B$. cinerea accounted for more than $50-60 \%$ of all fungi isolated.

Key words: fungi; diseases of Alpine lady-fern; Karkonosze Mountains

\section{Streszczenie}

Badania fitopatologiczne prowadzono w latach 2016-2017 w Karkonoskim Parku Narodowym. W trakcie analizy mykologicznej z porażonych tkanek wyizolowano łącznie 17 izolatów należących do 13 gatunków i 1 rodzaju grzybów. Z każdego typu objawu, takiego jak przebarwienie tkanki, przewężenie oraz złamanie nerwu wyizolowano grzyb Botrytis cinerea, który w każdym z tych przypadków stanowił powyżej 50-60\% udziału wszystkich wyizolowanych grzybów.

Słowa kluczowe: grzyby; choroby wietlicy alpejskiej; Karkonosze

\footnotetext{
${ }^{1}$ Uniwersytet Przyrodniczy we Wrocławiu, Katedra Ochrony Roślin

2Uniwersytet Przyrodniczy we Wrocławiu, Katedra Botaniki i Ekologii Roślin

pl. Grunwaldzki 24a, 50-363 Wrocław

${ }^{3}$ Centrum Rozwiązań Systemowych

Jaracza 80b/10, 50-305 Wrocław

*corresponding author: wojciech.pusz@upwr.edu.pl
} 


\section{Wstęp / Introduction}

Wietlica alpejska (Athyrium distentifolium Tausch ex Opiz) jest gatunkiem alpejsko-arktycznym występującym w środowiskach z długo zalegającą pokrywą śnieżną. Jest gatunkiem dysjunktywnym, obejmującym swym zasięgiem geograficznym obszary okołoarktyczne (Skandynawia, Kamczatka, Islandia, Grenlandia) oraz rejony górskie Europy i Azji (Alpy, Sudety, Karpaty, Kaukaz) (Hultén i Fries 1986). Wysokościowe rozmieszczenie gatunku mieści się w szerokim zakresie - od poziomu morza w południowo-wschodniej Grenlandii (Devold i Scholander 1933) do ponad 2770 m n.p.m. w Alpach austriackich (Polatschek 1997). W Polsce wietlica alpejska występuje w Sudetach i Karpatach, gdzie tworzy ziołorośla paprociowe oraz jest dominującym gatunkiem runa podzespołu paprociowego świerkowego boru górnoreglowego (Calamagrostio-Piceetum filicetosum) (Matuszkiewicz i Matuszkiewicz 1974; Stachurska-Swakoń 2008).

$\mathrm{Na}$ skutek wielkopowierzchniowego zamierania drzewostanów świerkowych w Karkonoszach, w drugiej połowie XX wieku, ekosystemy leśne stały się bardziej otwarte. Spowodowało to zwiększony dopływ światła do dna lasu i intensywny rozwój warstwy runa. W tym okresie wietlica alpejska była jednym z gatunków intensywnie zwiększających swój udział. Na haliznach w podzespole paprociowym świerkowego boru górnoreglowego powstawały rozległe płaty ziołorośli paprociowych, które stanowiły poważną konkurencję dla siewek drzew i spowalniały regenerację drzewostanu (Vacek i wsp. 1999).

Zamieranie wietlicy alpejskiej w Karkonoszach zachodzi nieprzerwanie od ponad 10 lat. Zjawisko to ma charakter wielkopowierzchniowy, obejmuje stopniowo wszystkie osobniki występujące w płacie i rozprzestrzenia się na kolejne płaty i stanowiska. Proces zamierania tego gatunku jest zjawiskiem nowym, nieodnotowanym do tej pory w literaturze (Mchaffie 2005). W pierwszej kolejności wystąpił on w płatach położonych w piętrze boru górnoreglowego, a następnie przenosił się również na wyższe stanowiska położone powyżej górnej granicy lasu. Objawy chorobowe, jak i przebieg procesu zamierania są specyficzne i powtarzają się na kolejnych stanowiskach.

Celem przeprowadzonych badań było poznanie składu gatunkowego grzybów zasiedlających zamierające rośliny wietlicy alpejskiej.

\section{Materiały i metody / Materials and methods}

Obserwacje przestrzennego przebiegu procesu zamierania prowadzono od 2008 roku, kiedy zaobserwowano pierwsze objawy tego zjawiska w borze górnoreglowym w rejonie Kopy oraz w rejonie Szrenicy. W latach 2016-2017 prowadzono obserwacje procesu zamierania na 12 stanowis- kach zlokalizowanych w Karkonoskim Parku Narodowym, natomiast szczegółowe badania fitopatologiczne były prowadzone na wybranych stanowiskach: na stokach Szrenicy, wzdłuż Mokrej Drogi oraz w rejonie Domku Myśliwskiego (w pierwszym roku badań). W sezonie 2017 kontynuowano badania w rejonie Mokrej Drogi oraz na Wydzieleniu „71f” i w rejonie Schroniska „Nad Łomniczką”. Pobieranie prób odbywało się w odstępach comiesięcznych w okresie od maja do końca października w każdym roku badań.

W celu wyizolowania grzybów z porażonych organów, podczas każdego wyjazdu terenowego pobranych zostało po 10 roślin z wyraźnymi objawami porażenia. Z porażonych organów wycinano zmienione chorobowo fragmenty, które następnie były odkażane powierzchniowo w $0,5 \%$ roztworze podchlorynu sodu przez 10 sekund. Kolejnym etapem było wyłożenie około $0,5 \mathrm{~cm}$ fragmentów tkanki na szalki Petriego z zestaloną pożywką PDA (Potato Dextrose Agar). Wyrastające kolonie grzybów były odszczepiane na skosy z pożywką PDA i oznaczane do gatunku na podstawie cech morfologicznych oraz molekularnych.

Diagnostyczne badania molekularne przeprowadzono w oparciu o izolaty grzybów w probówkach na skosach z pożywką (Pusz i Urbaniak 2017). Izolacja materiału genetycznego została wykonana za pomocą zestawu DNeasy Plant Mini Kit (50), w oparciu o głębokie mrożenie ciekłym azotem. Amplifikacja testowego fragmentu DNA - genu ITS została przeprowadzona $\mathrm{z}$ wykorzystaniem rekombinowanej polimerazy Taq (Thermo Scientific) specyficznych primerów (White i wsp. 1990). Produkty PCR (polymerase chain reaction) zostały oczyszczone za pomocą kolumn krzemionkowych zestawem (GeneJET PCR Purification Kit, Thermo Scientific) i wysłane do serwisu sekwencjonowania DNA (Genomed - Warszawa). Analiza wyników badań została przeprowadzona z wykorzystaniem programów do analizy DNA: FinchTV (2011) oraz BLAST (2016) (Corpet 1988).

\section{Wyniki i dyskusja / Results and discussion}

Przebieg procesu zamierania jest przestrzennie uporządkowany. Proces rozpoczął się w zbiorowisku boru górnoreglowego (Calamagrostio-Piceetum filicetosum) w rejonie Kopy i Szklarskiej Poręby, następnie rozprzestrzeniał się na sąsiednie, wyżej położone płaty ziołorośli paprociowych (Athyrietum distentifilii) na stokach Szrenicy i w Kotle Szrenickim oraz na stokach Kopy. W dalszej kolejności proces obejmował kolejne stanowiska w sposób uporządkowany przestrzennie, w pierwszej kolejności zachodził w płatach ziołorośli paprociowych sąsiadujących z dużymi połaciami paprociowego typu boru górnoreglowego. Lokalne uporządkowanie przestrzenne od zachodu na wschód obserwowano w płatach położonych w Karkonoszach Zachodnich. W obrębie wielu zamierających płatów również 
dało się zauważyć pewne przestrzenne uporządkowanie zamierające osobniki zwykle znajdowały się z jednej strony płatu i porażenie stopniowo obejmowało coraz większą liczbę roślin stopniowo przesuwając się w głąb płatu. We wczesnej fazie zamierania niektórych płatów można było dostrzec wyraźną granicę pomiędzy porażonymi i nieporażonymi osobnikami. Taki przebieg przestrzenny zjawiska jest typowy dla epidemii i sugeruje udział czynnika biotycznego stopniowo rozprzestrzeniającego się na kolejne osobniki, kolejne płaty na stanowisku i kolejne stanowiska.

Pierwsze objawy chorobowe na roślinach wietlicy alpejskiej widoczne były na przełomie maja i czerwca w postaci ciemniejących plam, zlokalizowanych w górnej partii nerwu głównego. Następnie nerw w tym miejscu ulegał złamaniu. W dalszej kolejności brunatnienie nerwu rozwijało się w kierunku nasady ogonka liściowego, a porażona tkanka ulegała stopniowej dekompozycji i wykruszała się. Proces ten powodował stopniowy zanik całego liścia od góry do dołu, tak że jeszcze w trakcie sezonu wegetacyjnego z liścia zostawały tylko dolne fragmenty ogonków liściowych. Wskutek tego procesu jeszcze przed naturalnym przebarwianiem się i więdnięciem liści ich biomasa niemal w całości ulegała dekompozycji. Innym obserwowanym objawem chorobowym było tworzenie się charakterystycznych deformacji wierzchołkowej części liścia, która wyglądała tak, jak gdyby pastorałowate zwinięcie, typowe dla wczesnej fazy rozwojowej liścia, które nie ulegało rozwinięciu. Następowało to na skutek porażenia nerwu liściowego i zahamowania jego przyrostu na długość. Deformacja ta przypominała nierozwinięty pastorał liścia paproci. Następnie miejsce deformacji przebarwiało się na ciemnobrunatny kolor. Ostatnim typem objawu chorobowego było przebarwianie się całego liścia, a następnie jego zasychanie.

Paprocie nie są roślinami, które są często porażane przez patogeny. Najbardziej kompleksowo zostały opisane choroby paproci rosnących w lasach w drugiej połowie XX wieku w stanie Oregon. Autor wśród sprawców chorób tych roślin wymienia grzyby z rodzaju Taphrina, Milesia, Fusarium (Sandeno 1962). Z kolei w Pakistanie stwierdzono występowanie na liściach grzybów patogenicznych z rodzaju Puccinia (Afshan i wsp. 2010). Podczas badań prowadzonych w Karkonoszach, grzyby z grupy Fusarium izolowano $\mathrm{z}$ tkanek wietlicy alpejskiej. Najczęściej był to gatunek Giberella avenacea, który zasiedlał złamane nerwy liściowe. Wydaje się, że jest to sytuacja jak najbardziej normalna, gdyż grzyby z rodzaju Fusarium, w tym G. avenacea, stanowią nieodłączny element zbiorowisk roślinnych (Pusz 2016), martwego drewna (Pusz i wsp. 2017b), a także powietrza atmosferycznego w Karkonoszach (Pusz i wsp. 2017a).

W trakcie analizy mykologicznej z porażonych tkanek wyizolowano łącznie 17 izolatów należących do 13 gatunków i 1 rodzaju grzybów (tab. 1). Z każdego typu objawu, takiego jak przebarwienie tkanki, przewężenie oraz złamanie nerwu wyizolowano grzyb Botrytis cinerea, który w każdym z tych przypadków stanowił 50 lub 60\% udziału wszystkich wyizolowanych grzybów. Gatunek ten jest typowym patogenem i zasiedla tkanki zarówno nieuszkodzone, jak i uszkodzone w wyniku działania innych czynników (zarówno abiotycznych, jak i biotycznych). W przypadku złamania tkanki można także zauważyć, że drugim dominantem są grzyby z rodzaju Fusarium (w tym G. avenacea). Są to typowe patogeny roślin, które mogą także rozwijać się na zamierającej i martwej tkance roślinnej. Typowymi saprotrofami są grzyby z rodzaju Trichoderma, Aspergillus, Penicillium oraz Alternaria alternata. Należy wspomnieć, że w przypadku objawu przypominającego galas nie wyizolowano żadnych kolonii grzybów.

Dominującym gatunkiem grzyba, który był izolowany ze wszystkich tkanek wietlicy alpejskiej, wykazujących objawy chorobowe był gatunek $B$. cinerea, który jest sprawcą szarej pleśni. Grzyb ten jest polifagiem, rozwijającym się w szerokim spektrum temperatury (Govrin i Levine 2000). Może powodować choroby zarówno roślin uprawnych, jak i dziko rosnących (Pusz 2016). O jego agresywności świadczy także fakt infekowania organów roślinnych w hodowli in vitro, a także gametofitów paproci (San Francisco i Cooper-Driver 1984). Wydaje się jednak, że w przypadku wietlicy alpejskiej to nie grzyby patogeniczne odpowiedzialne są za zamieranie tej rośliny w Karkonoszach. Prawdopodobnie grzyby stanowią jeden z elementów, który przyśpiesza ten proces. Być może sprawcą są zmieniające się na przestrzeni lat warunki wilgotnościowe w siedlisku (Migała i Pawliczek 2018), a te z kolei bezpośrednio mogą wpływać na zbiorowiska roślinne, a tym samym i zbiorowiska grzybów (w tym mykoryzowych) związanych $\mathrm{z}$ wietlicą alpejską (Krakowski 2018). Obecność grzybów mykoryzowych może oddziaływać na lepsze odnawianie się paproci oraz odporność roślin na czynniki abiotyczne i biotyczne (West i wsp. 2009). Potwierdzają to także inne publikacje. Dzięki grzybom mykoryzowym paprocie mogą rosnąć w niesprzyjających warunkach (Palmieri i Swatzell 2004). Takie badania były prowadzone również w przypadku innych gatunków paproci z rodzaju Athyrium (Matsuda i wsp. 2005). Zaburzenia w zbiorowiskach grzybów mykoryzowych mogą wpływać na zmniejszenie odporności wietlicy alpejskiej na porażenie przez grzyby, a także fitofagi.

Jednym $\mathrm{z}$ celów prowadzenia monitoringu zdrowotności roślin $\mathrm{w}$ zbiorowiskach cennych przyrodniczo oraz leżących na obszarach chronionych jest określenie zmian, jakie zachodzą w badanych zbiorowiskach roślinnych (Pusz 2016). Obserwacje procesu zamierania wietlicy alpejskiej prowadzone są w Karkonoszach już od wielu lat, jednak włączenie do badań typowych metod fitopatologicznych miało miejsce dopiero od 2014 roku (Pusz 2017). Dotychczas opisywany proces ma miejsce tylko w Karkonoszach, natomiast w Karpatach nie obserwuje się tego procesu w takim nasileniu (Fiala i wsp. 2011). 
Tabela 1. Grzyby zasiedlające zamierające rośliny wietlicy alpejskiej (Athyrium distentifolium) w Karkonoskim Parku Narodowym w latach 2016 i 2017

Table 1. Fungi occurring on Athyrium distentifolium in Karkonosze National Park in 2016 and 2017

\begin{tabular}{|c|c|c|c|c|c|}
\hline \multicolumn{6}{|c|}{2016} \\
\hline $\begin{array}{l}\text { Gatunek } \\
\text { Species }\end{array}$ & $\begin{array}{c}\text { Numer akcesu } \\
\text { Accession } \\
\text { number }\end{array}$ & $\begin{array}{l}\text { Kod izolatu } \\
\text { Isolate code }\end{array}$ & $\begin{array}{c}\text { Domek } \\
\text { Myśliwski } \\
{[\%]}\end{array}$ & $\begin{array}{c}\text { Mokra } \\
\text { Droga } \\
{[\%]}\end{array}$ & $\begin{array}{c}\text { Szrenica } \\
{[\%]}\end{array}$ \\
\hline Alternaria alternata & MH170874 & $11 \mathrm{gg}$ & - & - & 5 \\
\hline Aspergillus clavatus & MH170869 & $1 \mathrm{p} 1,5 \mathrm{pl}$ & 10 & - & 2 \\
\hline Botrytis cinerea & MH170868 & $4 \mathrm{p} 1$ & 50 & 60 & 60 \\
\hline Giberella avenacea & MH170873 & $3 \mathrm{p} 1$ & 30 & - & 30 \\
\hline Hypocera rufa & MH170871 & $9 \mathrm{p} 1$ & - & 15 & - \\
\hline Penicillium lividum & MH170878 & $7 \mathrm{p} 1$ & 5 & - & - \\
\hline Talaromyces purpuragenus & MH170875 & $2 \mathrm{p} 1$ & 5 & - & 3 \\
\hline Trichoderma viridae & MH170870 & $23 \mathrm{p} 1$ & - & 20 & - \\
\hline Trichoderma spp. & MH170872 & $5 \mathrm{p} 1$ & - & 5 & - \\
\hline \multicolumn{6}{|c|}{2017} \\
\hline $\begin{array}{l}\text { Gatunek } \\
\text { Species }\end{array}$ & $\begin{array}{c}\text { Numer akcesu } \\
\text { Accession } \\
\text { number }\end{array}$ & $\begin{array}{l}\text { Kod izolatu } \\
\text { Isolate code }\end{array}$ & $\begin{array}{c}\text { Mokra } \\
\text { Droga } \\
{[\%]}\end{array}$ & $\begin{array}{c}\text { Wydzielenie } \\
\text {,71f" } \\
{[\%]}\end{array}$ & $\begin{array}{c}\text { Schronisko } \\
\text { „Nad } \\
\text { Łomniczką" } \\
{[\%]}\end{array}$ \\
\hline Alternaria alternata & MH170880 & $1 \mathrm{gg}$ & 30 & 20 & 10 \\
\hline Botrytis cinerea & MH170879 & $231 \mathrm{bgg}$ & 50 & 50 & 50 \\
\hline Cladosporium cladosporioides & MH170884 & $8 g g$ & - & 5 & - \\
\hline Giberella avenacea & MH170885 & $231 \mathrm{agg}$ & - & 5 & 30 \\
\hline Penicillum commune & MH170881 & $4 g g$ & 10 & - & - \\
\hline Penicillium minioluteum & MH170883 & $\operatorname{logg}$ & - & 10 & - \\
\hline Penicillium thomi & MH170886 & $9 g g$ & - & - & 10 \\
\hline Trichoderma harzianum & MH170882 & $3 g g$ & 10 & 10 & - \\
\hline
\end{tabular}

\section{Wnioski / Conclusions}

Przyczyną pojawiających się przebarwień na nerwach A. distentifolium, przewężeń oraz złamania tkanki był kompleks grzybów zarówno patogenicznych, jak i saprotroficznych z wyraźną dominacją $B$. cinerea.
Badania sfinansowano ze środków funduszu leśnego Państwowego Gospodarstwa Leśnego „Lasy Państwowe” przekazanych Karkonoskiemu Parkowi Narodowemu w latach 2016-2017.

\section{Literatura / References}

Afshan N.S., Iqbal S.H., Khalid A.N., Niazi A.R. 2010. A new anamorphic rust fungus with a new record of Uredinales from Azad Kashmir, Pakistan. Mycotaxon 112: 451-456. DOI: 10.5248/112.451.

BLAST. Basic Local Alignment Search Tool. 2016. http://blast.ncbi.nlm.nih.gov/Blast.cgi [Accessed: 21.05.2018].

Corpet F. 1988. Multiple sequence alignment with hierarchical clustering. Nucleic Acids Research 16 (22): 10881-10890.

Devold J., Scholander P.F. 1933. Flowering Plants and Ferns of Southeast Greenland. I Kommisjon hos Jacob Dybwad, Oslo, 56 pp.

Fiala K., Tůma I., Holub P., Záhora J. 2011. Ecological analysis of herbage layer of disturbed spruce stands in the National Nature Reserve Kněhyně-Čertův mlýn in the Beskydy Mts. Ekológia 30 (3): 381-395. DOI: 10.4149/ekol_2011_03_381.

FinchTV. 2011. Software Developer of Next Gen Sequencing DNA Genetic Analysis and LIMS. http://www.geospiza.com/Products/ finchtv.shtml [Accessed: 21.05.2018].

Govrin E.M., Levine A. 2000. The hypersensitive response facilitates plant infection by the necrotrophic pathogen Botrytis cinerea. Current Biology 10 (13): 751-757. DOI: 10.1016/S0960-9822(00)00560-1.

Hultén E., Fries M. 1986. Atlas of North European Vascular Plants: North of the Tropic of Cancer. Königstein, Koeltz Scientific Books, 498 pp. 
Krakowski K.H. 2018. Zmiany w opadach atmosferycznych i pokrywie śnieżnej oraz ich skutki. Karkonosze 1 (291): 9-10.

Matsuda Y., Murahashi F., Nakanishi K.I., Ito S.I., Kimoto M. 2005. Arbuscular mycorrhizas on Athyrium yokoscense and A. niponicum grown at a lead-contaminated site. Mycoscience 46 (4): 261-264. DOI: 10.1007/S10267-005-0241-0.

Matuszkiewicz W., Matuszkiewicz A. 1974. Mapa zbiorowisk roślinnych Karkonoskiego Parku Narodowego. Ochrona Przyrody 40: 45-112.

Mchaffie H.S. 2005. Athyrium distentifolium Tausch ex Opiz (A. alpestre (Hoppe) Rylands ex T. Moore-non-Clairv.) including A. distentifolium var. flexile (Newman) Jermy. Biological flora of the British Isles No. 241. Journal of Ecology 93 (4): 839-851. DOI: 10.1111/j.1365-2745.2005.01037.x.

Migała K., Pawliczek P. 2018. Globalne ocieplenie, a naturalne środowisko Karkonoszy. Karkonosze 1 (291): 3-4.

Palmieri M., Swatzell L.J. 2004. Mycorrhizal fungi associated with the fern Cheilanthes lanosa. Northeastern Naturalist 11 (1): $57-66$. DOI: 10.1656/1092-6194(2004)011[0057:MFAWTF]2.0.CO;2.

Polatschek A. 1997. Flora von Nordtirol, Osttirol und Vorarlberg. Band 1. Tiroler Landesmuseum Ferdinandeum, Innsbruck, 1024 pp. ISBN 978-3950027839.

Pusz W. 2016. Plants' healthiness assessment as part of the environmental monitoring of protected mountainous area in the example of Karkonosze (Giant) Mts. (SW Poland). Environmental Monitoring and Assessment 188 (10): 544. DOI: 10.1007/s10661-016$5551-5$.

Pusz W. 2017. Fitopatolodzy wrocławscy - historia badań Karkonoszy. Opera Corcontica 54 (2): 91-98.

Pusz W., Urbaniak J. 2017. Foliar diseases of willows (Salix spp.) in selected locations of the Karkonosze Mts. (the Giant Mts). European Journal of Plant Pathology 148 (1): 45-51. DOI: 10.1007/s10658-016-1067-7.

Pusz W., Weber R., Dancewicz A., Kita W. 2017a. Analysis of selected fungi variation and its dependence on season and mountain range in southern Poland-key factors in drawing up trial guidelines for aeromycological monitoring. Environmental Monitoring and Assessment 189 (10): 526. DOI: 10.1007/s10661-017-6243-5.

Pusz W., Zwijacz-Kozica T., Patejuk K., Uklańska-Pusz C. 2017b. Zbiorowiska grzybów mikroskopijnych zasiedlających martwe drewno w Karkonoszach i Tatrach. Edukacja Biologiczna i Środowiskowa 1: 22-26.

Sandeno J.L. 1962. Diseases of western sword-fern Polystichum munitum (Kaulf.) Presl. Thesis. Oregon State University, USA, 162 pp.

San Francisco M., Cooper-Driver G. 1984. Anti-microbial activity of phenolic acids in Pteridium aquilinum. American Fern Journal 74 (3): 87-96. DOI: $10.2307 / 1546543$.

Stachurska-Swakoń A. 2008. The role of Athyrium distentifolium Tausch ex Opiz in formation of tall-herb communities in the Tatra National Park (the Western Carpathians). In: "Club Mosses, Horsetails and Ferns in Poland - Resources and Protection" (E. Szczęśniak, E. Gola, eds.). Institute of Plant Biology, University of Wrocław, Wrocław: 81-94.

Vacek S., Bastl M., Lepš J. 1999. Vegetation changes in forests of the Krkonoše Mts. over a period of air pollution stress (1980-1995). Plant Ecology 143 (1): 1-11. DOI: 10.1023/A:1009833313509.

West B., Brandt J., Holstien K., Hill A., Hill M. 2009. Fern-associated arbuscular mycorrhizal fungi are represented by multiple Glomus spp.: do environmental factors influence partner identity? Mycorrhiza 19 (5): 295-304. DOI: 10.1007/s00572-009-0234-5.

White T.J., Bruns T., Lee S., Taylor J.W. 1990. Amplification and direct sequencing of fungal ribosomal RNA genes for phylogenetics. In: "PCR Protocols: A Guide to Methods and Applications" (M.A. Innis, D.H. Gelfand, J.J. Sninsky, T.J. White, eds.). New York Academic Press Inc.: 315-322. 